Performance. Volume 27 Nomor 2 Tahun 2020, 01-12

\title{
FACTORS THAT INFLUENCE TO SUSTAINABILITY OF MSME MUFFLER INDUSTRY IN PURBALINGGA REGENCY
}

\author{
Faizal Dwi Kurniawan ${ }^{1}$, Eliada Herwiyanti ${ }^{1 *}$, Bambang Setyobudi Irianto ${ }^{1}$ \\ ${ }^{1}$ Accounting, Faculty of Economics and Business, Universitas Jenderal Soedirman, Indonesia \\ *Email corresponding author: eliadaherwiyanti@gmail.com \\ Received 21/11/2019 Direvisi 07/09/2020 Diterbitkan 30/09/2020
}

\begin{abstract}
Financial literacy, accounting literacy, and transactional leadership style are needed by the owners for sustainability of their business, especially for MSME sector. The good level of the financing and leadership is the success key to maintain the sustainability of the business. Whether financial literacy, accounting literacy, and transactional leadership style can influence the sustainability in muffler industry Purbalingga? This research was conducted using a quantitative descriptive method, that is based on the questionnaire and interviews with respondent. The object of this research is MSMEs muffler industry in Purbalingga. The total sample in this research are 76 sample from the population 166 industry spread in 6 subdistrict in Purbalingga. The result of this research indicate that the financial literacy, accounting literacy and transactional leadership style have a positive effect to the sustainability of muffler industry. The better the financial literacy, the better the business plan and decisions. Having good accounting literacy in the business tend to be able to produce the good financial standard report, the quality of the financial standard report can help the business to get investment and loan. The good implementation leadership style can help the business sustainability.
\end{abstract}

Key Words: financial literacy, accountng literacy, transactional style, MSME, muffler industry

\section{INTRODUCTION}

Sustainability of the business is very important for new business and long-running business. Sustainability of the business is a benchmark for assessing the performance business effectiveness. A business needs the concept to maintain the sustainability a business to see the effectiveness of the business by creating the short-term goal and long-term goal. The development of the industry in the Purbalingga has a very important contribution to the absorption of labor, for example in the famous industry in Purbalingga today, namely the muffler industry. Some sub-districts in Purbalingga currently have their own muffler industry. Until now they have helped people to be more productive so that they can reduce unemployment. The muffler industry already increased the total of the industry every year from 2010 until 2017. There has been a lot of muffler industry that has started to dominate the small and medium micro industrial business in Purbalingga. Until now, there are 6 subdistricts that produce mufflers in the Purbalingga. The six regions are Purbalingga, Kalimanah, Kutasari, Padamara, Bojongsari, and Mrebet sub-districts. The total of all industries from the 6 sub-districts are around 166 industries in 2017, this amount decreases from the previous year which reached 173 industries in 2016.

The concept of sustainability assumes that a business will sustain itself in the future. Schaltegger et al. (2012) and Ariwibawa (2016) state that sustainability business is measured based on the company's success in innovating, managing employees and customers, and returning initial capital. Handayani (2007) states that the sustainability of a business is a business condition in which there are ways to maintain, develop, protect resources and meet existing needs in a business. The way that can do to maintain sustainability is by increasing the financial literacy of the business (Puspaningtyas, 2017). The importance of financial literacy makes business well managed from a 


\section{PERFORMANCE}

Jurnal Personalia, Financial, Operasional,

Marketing dau Sistem Informasi

Performance. Volume 27 Nomor 2 Tahun 2020, 01-12

financial perspective, financial literacy can make the owner in financing more effective. Widayanti et al. (2017) state that financial literacy can be an important factor and influence the sustainability of a business. Fatoki (2014) proves that financial literacy can influence the sustainability of a business.

Another way that can do to maintain the sustainability of a business is by increasing accounting literacy. Wibowo (2015) stated that using accounting information had an effect on business success. Juita (2016) said that the majority of MSMEs studied had understood the importance of accounting information on business success. In addition to an understanding of financial and accounting literacy, to maintain the sustainability of a business is inseparable from a leader who is able to make every element in the company contribute maximally. The implementation of the transactional leadership style is considered can make workers motivated so that the business carried out will be more effective. Bass (2006) states that transactional leadership is leadership in which leaders support employees or subordinates to work by maximizing resources, so they can get an appreciation for productivity, and achieving effective tasks. Gurerk (2017) said in his research that rewards are more effective against controlling team performance than leading by example. Using the reward is more attractive to employees. They are more motivated and produce better quality work.

This research refers from previous research, about the benefits of financial literacy for business sustainability (Puspaningtyas, 2017). The research is a reference for current researchers to develop financial literacy in the sustainability of a business. In this study, there are additions to several independent variables to distinguish from previous studies. The addition of independent variables in this study are Accounting Literacy (Wibowo, 2015) and Transactional Leadership Style (Bass \& Ronald, 2006).

\section{LITERATURE REVIEW AND HYPOTHESIS DEVELOPMENT}

\section{Resources Based Theory}

Resources based theory discusses how the companies can process and utilize all of their resources maximally to achieve competitive advantage (Barney, 1991). Competitive advantage is something that is inherent in the company and difficult to imitate by other companies. Companies should utilize and develop their own competitive advantages. Porter (1985) in his article "Competitive Advantage: Creating and Sustaining Superior Performance". Resources are considered important and have a role in creating competitive advantage (tangible asset and intangible asset). PSAK 19 provides the definition of intangible assets as non-monetary assets that identified without physical form. Intellectual capital is an important concept that provides knowledge-based resources and describes intangible assets.

Intellectual capital is classified into three types of capital, first, human capital is concerns about competency, skills, brainpower, expertise, creativity, problem-solving capability, leadership, ownersial and managerial skills and tacit knowledge possessed by company employees. Second, structural capital is the knowledge capability of the company in the form of technology, methodology, and processes, which makes it able to respond to market needs and challenges. Third is customer capital concerns relationships, feedback, input on products or services, suggestions, experiences, and tacit knowledge from customers. The term customer is expanded to include suppliers, distributors, and authorities or other players who can contribute to the value chain.

This research is more concerns about the skills, knowledge, and the leadership of the human capital. Human capital is a very important element of intellectual capital because it can create competitiveness for organizations or companies. Human capital is the ability of each member of the organization to be used in the process of creating intellectual assets (Sangkala, 2006). Research Edvinsson and Malone (1977) stated that human capital is a combination of knowledge, 


\section{PERFORMANCE}

Jurnal Personalia, Financial, Operasional,

Marketing dau Sistem Informasi

Performance. Volume 27 Nomor 2 Tahun 2020, 01-12

skills, innovation, and the ability of employees to carry out their duties including company values, culture, and philosophy.

\section{Sustainability of the Business}

Handayani (2007) sustainability of the business is a business condition, where the form of consistency of business conditions. The sustainability of a business is supported by several factors according to Saboet (1994) the sustainability criteria for business include an increase in production volume, additional labor, the addition of production equipment by hoping for an increase in production capacity and additional capital from retained earnings. Leigh et al. (1990) in Aribawa (2016) suggest several factors that influence the sustainability of Small and Medium Enterprises (SMEs) are: a successful product strategy, return on capital has been achieved, and the ability of managers to create and exploit existing market opportunities and overcome difficulties that arise.

\section{Financial Literacy}

Financial literacy is knowledge about the financial concepts, the ability to communicate understanding related to financial concepts, ability in managing business finance, and the ability to strategically and relatively appropriate business decisions in certain situations (Fatoki, 2014; Aribawa, 2016). In a book published by the OJK (Financial Services Authority) entitled the National Strategy for Inclusive Finance (2012), the classification of category levels is explained which explains how much understanding of financial products and their levels are as follows: (1) Well literate means having knowledge and belief about financial service institutions and financial services, including the features, benefits and risks, rights and obligations related to financial products and services, and having skills in using financial products and services. (2) Sufficient literate means having knowledge and beliefs about financial service institutions and financial products and services, including features, benefits and risks, rights and obligations related to financial products and services. (3) Less Literate means having only knowledge about financial services institutions and financial products and services. (4) Not literate means having no knowledge and beliefs about financial services institutions and financial products and services, and do not have the skills to use financial products and services.

\section{Accounting Literacy}

Accounting literacy is ability to understand clearly and communicate financial situations and events (www.accountingliteracy.org, 2019). Accounting literacy is a precursor to financial literacy. Accounting literacy is not a general term that used in the literature, but the broader term 'financial literacy' is widely used. Williams (2005) notes that students who master the concepts contained in financial liabilities and accounting will be good at managing their finances. Coates et al. (2007) develop criteria for accounting literacy based on mandatory disclosures of Important Accounting Policies and Estimates from the annual report. Rosacker et al. (2009) look at it as the ability to make informed judgments and to take effective actions regarding the using and managing the money currently and in the future.

Coates et al. (2007) develop criteria for accounting literacy based on mandatory disclosures of Important Accounting Policies and Estimates from the annual report. Their criteria focus on understanding the business models, recognition and measurement of GAAP and IFRS, management assessment and estimation according to the business model and implications of management choices for potential financial reporting manipulation. These criteria are consistent with Hills and Weil (2004) that propose the importance of knowledge of financial information on the satisfaction of audit committee in carrying out its responsibilities. 


\section{Transactional Leadership Style}

Leadership is a process where someone influences other people to achieve goals and direct the organization in a way that makes it more cohesive and coherent. Leadership science has increasingly developed along with the dynamics of the development of human life (Tika, 2006). Bass (2006) mentions 3 leadership styles, which is transformational, transactional, and passive/avoidant. Bass (2006) states that transactional leadership is leadership in which leaders support employees or subordinates to work by maximizing resources, so they can get an appreciation for productivity, and achieving effective tasks.

Gurerk (2017) said in his research that rewards are more effective in controlling team performance than leading by example. Contingent rewards represent relationships based on punishment and reward in return for performance (Flynn, 2009). Bass (2006) states that when using contingent rewards, a leader completes a job or task by making a salary rise agreement for employees who perform well and punish poor performance.

\section{Effects of Financial Literacy on Sustainability of the Business}

Research-Based Theory relates to the management and use of resources owned with the sustainability of the business. Wernerfelt (1984) explains that according to RBT's view, companies will overcome in business competition and obtain good financial performance by owning, controlling and utilizing important strategic assets. Strategic assets can be in the form of tangible assets and intangible assets. One example of intangible assets is intellectual capital.

Fatoki (2014) that proved that financial literacy influences the sustainability business Widayanti et al. (2017) stated that financial literacy can be an important factor and influences the sustainability of the business, knowledge to manage finances, make a plan with current finance, and make decision from the financial conditions. Puspaningtyas (2017) state that financial literacy has proven to provide benefits to business sustainability, so using financial literacy is an effort to improve business. Therefore, policymakers must consider developing a work program on an ongoing basis in order to improve financial literacy for the owner. An owner who has a good level of financial literacy is expected can to effectively manage their business finances.

Knowledge of business owners about financial literacy is a part of human capital in the form of skills and tacit knowledge. In several previous research, it was also proven that financial literacy can influence sustainability of the business. Therefore financial literacy can influence sustainability of the business because it is part of human capital.

$\mathrm{H}_{1}$ : Financial Literacy has a positive effect on Sustainability of The Business.

\section{Effects of Accounting Literacy on Sustainability of the Business}

Accounting literacy is basically an advanced understanding of financial literacy. In accounting, literacy discusses capabilities owned by the owner about understanding of accounting factors such as financial statements, income statements, capital change reports, and trial balance. As one of the intangible assets, it should be used optimally to get better and more effective results, and for the business, it can be sustainable with implementing accounting literacy. Wibowo (2015) stated that using accounting information has an effect on business success.

Juita (2016) said that the majority of MSMEs studied had understood the importance of accounting information for the success of their business. The importance of financial information for MSMEs can be seen from the large benefits of financial information as a basis for evaluating the successful performance of MSME, as a basis for preparing business plans for the following year, and as consideration for making other important decisions. Liu \& Akhtar (2018) said that the contribution to the literature process is by offering greater intuition into important parts of financial statements in decision making. Various decisions depend solely on financial statement 
information and have a significant impact on sustainability of the business. Therefore, financial statements must be used by an owner in the company, for better decision making.

$\mathrm{H}_{2}$ : Accounting Literacy has a positive effect on Sustaniability of The Business.

\section{Effects of Transactional Leadership on Sustainability of the Business}

Leadership is a human capital that can be owned by everyone. A leader must have the capacity to analyze and create a working environment that is in accordance with their business. The appropriate leadership style for the business can maximize business performance. Giving reward and punishment is the implementation of a transactional leadership style. Kowalewski (2012) found that that rewards are more valuable. Economic awards will be more useful for small business owners and managers to develop their businesses. The reward program is used to respect and motivate their employees. Gurerk \& Scheuermann (2017) found that rewards are more effective in controlling team performance than leading by example. Using the reward is more attractive to employees so they are more motivated and produce the good quality product. Panekenan et al. (2019) found the results of the research that rewards and punishments significantly affect employee performance simultaneously and partially. Employees feel valued by the gifts given by the company and that encourages employee motivation to work harder and make better performance. Employees get the punishment in a positive way like a lesson and make punishment a driving force to motivate them more and create better performance.

Edirisooriya (2014) stated that rewards can affect employees to perform assigned tasks efficiently and effectively. The implementation of this reward aims to achieve a sustainable competitive advantage. From the explanation above, the transactional leadership style is also part of the resources based theory. As a part of the RBT, the quality of the transactional leadership style must be maximized by a business because it can help to maintain the sustainability of a business. Increased business effectiveness can be said that the business runs in accordance with the expectations desired by the leader.

$\mathrm{H}_{3}$ : The Transactional Leadership Style has a positive effect on Sustainability of the Business.

\section{RESEARCH METHODOLOGY}

The type of this research is quantitative research with the primary data. The object of this research is a muffler industry in Purbalingga Regency. The data collection of this research by distributing the questionnaire and interviewing the respondent. Population in this research are all muffler industries in 6 subdistricts Purbalingga with the total 166 muffler industry. The sample of this research using purposive random sampling technique with the criteria as follows: (1) MSME owners who have received training in managing and developing MSMEs. (2) MSME muffler Owners who have recorded transactions and financial statements. The sample in this research are MSME who fulfill the criteria are 50 industry, so the sample are minimum 50 industry.

Interviews were conducted for the muffler Industry MSME Owners to collect data on the number of employees, absence, employee turnover, organizational structure, operational standards and the ability to understand financial information and accounting information. In this research, it is conducting interviews with business owners regarding the number of employees, absence, employee turnover, organizational structure, operational standards and the ability to understand financial information and accounting information in the Purbalingga muffler industry. The questionnaire is an instrument for data collection, where participants or respondents fill in the questions given by the researcher. Researchers can use questionnaires to obtain data related to the thoughts, feelings, attitudes, beliefs, values, perceptions, and behaviors of the respondents. This researcher using pilot test to test the normality, validity and reliability of the data before distribute the instrument to real sample. 
Researchers can use measurements of various characteristics using the Cristensen questionnaire (2010) in Sugiyono (2013). Measurement of questionnaires in this study using a Likert Scale, the score given to each respondent's answer is: (1) Strongly Agree Answer is equivalent to a score of 5. (2) Agree Answer is equivalent to a score of 4. (3) Neutral Answers is equivalent to a score of 3. (4) The Disagree Answer is equivalent to a score of 2. (5) Strongly Disagree Answer is equivalent to a score of 1.

This study uses questionnaire as a data collection instrument. The design of the questionnaire covered 6 parts. Part 1 was enquired data of the owner or entrepreneur such as gender, age, level of education, business experience, total employee, total asset, product, training, and customer. Meanwhile, for the Part 2 enquired about financial literacy, Part 3 is about accounting literacy, Part 4 is transactional leadership style, Part 5 is sustainability of a business, and Section 6 is open questions about 4 variables.

Table 1. Main Section of the Questionnaire

\begin{tabular}{cl}
\hline Part & Main Section \\
\hline Part 1 & Data Of The Owner \\
\hline Part 2 & Financial Literacy \\
\hline Part 3 & Accounting Literacy \\
\hline Part 4 & Transactional Leadership Style \\
\hline Part 5 & Sustainability Of A Business \\
\hline Part 6 & Open Questions \\
\hline
\end{tabular}

The sustainability of a business is supported by several factors according to Saboet (1994). The financial literacy factors influencing variables by Nababan (2012). The indicators accounting literacy used by Roslan. N, et al. (2018) to measure accounting variables. The indicator used to measure the Transactional Leadership Style variable by Pradana \& Fuadati (2016).

Table 2. Questionnaire Item

\begin{tabular}{l}
\hline Sustainability of a Business Variable $(\mathrm{Y})$ \\
\hline Increase in production volume \\
\hline Additional workforce \\
\hline Additional production equipment \\
\hline Increased production capability \\
\hline Additional capital from retained earnings. \\
\hline Financial Literacy Variable $\left(\mathrm{X}_{1}\right)$ \\
\hline Basic knowledge of personal finance \\
\hline Savings and loans \\
\hline Investment \\
\hline Insurance \\
\hline Risk management \\
\hline Accounting Literacy Variable $\left(\mathrm{X}_{2}\right)$ \\
\hline Making Records \\
\hline Availability of Financial Statements \\
\hline Monthly recap \\
\hline The difference between sales revenue and net income \\
\hline Separation of personal wealth with business capital \\
\hline Calculate cash received and cash payments \\
\hline Transactional Leadership Style Variable $\left(\mathrm{X}_{3}\right)$ \\
\hline Contingent rewards \\
\hline Active management \\
\hline Passive management \\
\hline Laissez-faire leaders \\
\hline
\end{tabular}


The technique to analyze the data is use data instrument test, descriptive statistics test, classic assumption test, multiple linear regression analysis test, goodnes of fit test, and the last hypothesis test. The multiple regression test equation as follows:

$$
Y=a+b_{1} X_{1}+b_{2} X_{2}+b_{3} X_{3}+e
$$

Notes:

$Y=$ Sustainability Business

$X_{1}=$ Financial Literacy

$X_{2}=$ Accounting Literacy

$X_{3}=$ Transactional Leadership Style

$\mathrm{a}=$ Constant

$b_{1}=$ Regression coefficient of $X_{1}$

$b_{2}=$ Regression coefficient of $X_{2}$

$b_{3}=$ Regression coefficient of $X_{3}$

$\mathrm{e}=$ error (interfering factor outside the model)

\section{RESULT AND DISCUSSION}

\section{Data Analysis \\ Validity and Reliability Test}

The results of the test instrument data performed, indicate that all data tested is valid, reliable, and normal. The results of the validity test showed that the entire questionnaire instrument had a value greater than the value of the t table. In the results of the reliability test conducted showed that the overall data of the questionnaire had a value of more than 0.06 so that the data was declared reliable.

\section{Classic Assumption Test}

The results of the classic assumption test present that if the data meets the requirements for a regression test. In the results of normality tests carried out indicate if the value of the results obtained are more than 0.05 so that the data is declared normal. on the multicollinearity test results, the tolerance value is more than $10 \%$ and the VIF value is less than 10 so that there is no multicollinearity. In the heteroscedasticity test results for the three independent variables showed each has a value that exceeds 0.05 so that there are no symptoms of heteroscedasticity.

\section{Descriptive Statistics}

The results of processing descriptive statistical data are presented in the table as follows:

Table 3. Descriptive Statistics

\begin{tabular}{lcccc}
\hline Variable & Minimum & Maximum & Mean & Std. Deviation \\
\hline Sustainability of a Business & 15 & 25 & 18.91 & 2.954 \\
Financial Literacy & 15 & 25 & 18.64 & 2.404 \\
Accounting Literacy & 15 & 30 & 23.12 & 3.673 \\
Transactional Leadership Style & 10 & 20 & 15.26 & 2.352 \\
\hline
\end{tabular}

Source: Result of research (2019)

Based on Table 3, the first variable is sustainability of a business $(Y)$ the total respondent are 76 , and the minimum value answer are 15 with the maximum value are 25 . The mean value of $Y$ variable are 18.91 with the standard deviations value are 2.954. It means that the mean value is greater than the standard deviation value, it is indicates that $Y$ variable is good. Financial Literacy $\left(X_{1}\right)$ that can be seen $\mathrm{N}$ or total respondents are 76 , and the minimum value answers are 15 , for the answer to the highest value are 25 . The mean is obtained with total value 18.64 with the standard deviation 2.404. It is means that the mean value is greater than the standard deviation, 
Performance. Volume 27 Nomor 2 Tahun 2020, 01-12

it is indicates that the $X_{1}$ variable is good. The results of the test indicate that standard deviation is a reflection of low deviations, so the data distribution show normal result.

In variable Accounting Literacy $\left(\mathrm{X}_{2}\right)$ that can be seen $\mathrm{N}$ or total respondents are 76 , and the minimum value are 15 , for the maximum value answers are 30 . The mean is obtained with total value 23.12 with the standard deviation 3.673. It is means that the mean value is greater than standard deviation, it is indicate that the $X_{2}$ variable is good. The results of the test indicate that standard deviation has a low reflection from the standard deviations, so the data distribution is normal. In the Table 1 that can be seen $\mathrm{N}$ or total respondents are 76 , the minimum values for the variable transactional leadership style $\left(X_{3}\right)$ are 10 , and for the highest value answers are 20. The mean or the average value of this variable are 15.26 with the standard deviation value are 2.352. It is means that the mean value is greater than standard deviation, it is indicate that the $X_{3}$ variable is good. The results of the test indicate that standard deviation has a low reflection to the deviations, so the data distribution showing a normal results.

\section{Hypothesis Test result}

Data analysis for hypothesis testing in this study is using multiple regression analysis. The result from examining the three independent variables that are financial literacy, accounting literacy, and transactional leadership style have an effect to the the sustainability of business in muffler industry in Purbalingga. The table below discussed the results of multiple regression analyses. In this case, the variables used are Financial Literacy, Accounting Literacy, and Transactional leadership style, and its effect on The Sustainability of business. Gujarati (2013) make a equation of regression models that can be formulated:

$$
Y=\beta 1 \times 1+\beta 2 \times 2+\beta 3 \times 3+e
$$

Table 4. Multiple Regression Analysis Result

\begin{tabular}{llcc} 
No. & Variable & Regresion Standardized coefficient & Sig. \\
\hline 1 & Financial Literacy $\left(X_{1}\right)$ & 0.245 & 0.009 \\
2 & Accounting Literacy $\left(X_{2}\right)$ & 0.273 & 0.005 \\
3 & Transactional Leadership Style $\left(X_{3}\right)$ & 0.450 & 0.000 \\
\hline Source: Result of research (2019) & &
\end{tabular}

Table 4 show that the variable $X_{1}$ has a significance of 0.009 for $X_{2}$ with a significance of 0.005 , and for $X 3$ it has a significance of 0,000 . The three independent variables have a significance value of less than 0.05 . So it can be concluded that the multiple linear regression analysis test has good results because the three independent variables are worth less than 0.005 which has a significant effect on the dependent variable.

The result of $\mathrm{F}$ test is the Fvalue is greater than $\mathrm{F}$ table and the significant value is less than 0.005 . It can be concluded that the selected regression model is appropriate for this study. The result of Determination Coefficient Test is 0.625 , it means that the rsquare value is $62,5 \%$. While the remaining $37.5 \%$ are explained by other variables outside this research model.

The hypothesis testing used to determine the effect of each independent variable individually on the dependent variable. The table presents the overall t-test results in this research as follows:

Table 5. Hypothesis Test result

\begin{tabular}{ccccc}
\hline Model & T count & T table & Sig. & Result \\
\hline $\mathrm{X}_{1}$ & 2.667 & 1.993 & 0.009 & Significantly positive effect \\
$\mathrm{X}_{2}$ & 2.868 & 1.993 & 0.005 & Significantly positive effect \\
$\mathrm{X}_{3}$ & 5.413 & 1.993 & 0.000 & Significantly positive effect \\
\hline
\end{tabular}

Source: Result of research (2019) 


\section{PERFORMANCE}

Jurnal Personalia, Financial, Operasional,

Marketing dau Sistern Informasi

Performance. Volume 27 Nomor 2 Tahun 2020, 01-12

This test shows a significantcy level is 0.05 . Table 5 presents the value of $t$ count for each independent variable. If $\mathrm{t}$ arithmetic is greater than $\mathrm{t}$ table then $\mathrm{H} 1$ is rejected, and if $\mathrm{t}$ arithmetic is greater than $\mathrm{t}$ table then $\mathrm{H} 1$ is accepted which means that there is an influence of independent variable on dependent variable.

\section{Financial Literacy Variable}

The results of the t-test on financial literacy variable show the t-value of 2.667 with a probability of 0.009 . Since the t-value is greater than the t-table of 1.993 and the probability is smaller than 0.05 , it can be concluded that $\mathrm{H}_{1}$ is accepted. Which means that financial literacy has a significant influence on the sustainability of a business.

\section{Accounting Literacy Variable}

The results of the t-test on accounting literacy variable show the t-value of 2.868 with a probability of 0.005 . Since the t-value is greater than the t-table of 1.993 and the probability is smaller than 0.05 , it can be concluded that $\mathrm{H}_{2}$ is accepted. Which means that accounting literacy has a significant influence on the sustainability of a business.

\section{Transactional Leadership Style Variable}

The results of the t-test on transactional leadership style variable show the t-value of 5.413 with a probability of 0.000 . Since the t-value is greater than the t-table of 1.993 and the probability is smaller than 0.05 , it can be concluded that $\mathrm{H}_{3}$ is accepted. Which means that financial literacy has a significant influence on the sustainability of a business.

\section{DISCUSSION}

The first hypothesis of this study states that financial literacy affects the sustainability of a business. The results of the hypothesis show that financial literacy has an effect on the sustainability of a business which means the first hypothesis is accepted. Human capital in RBT theory can affect the sustainability of a business. This is because financial literacy is a part of human capital. Financial literacy is a form of human capital that discusses tacit knowledge and skills. In this study, the utilization of knowledge and skills have a role to help maintain the sustainability of a business. The results of this study are in line with the results of Puspaningtyas (2017) and Fatoki (2014) research. The results of the research indicated that financial literacy has a positive influence on the sustainability of a business. This is because most of muffler owners have an awareness of the importance of financial literacy. Financial literacy can help the owners manage their business.

The second hypothesis of this study states that accounting literacy affects the sustainability of a business. The results of hypothesis show that accounting literacy has a significant positive effect on the sustainability of a business which means the second hypothesis is accepted. In this study accounting literacy is a form of human capital that discusses about tacit knowledge and skills. This includes further knowledge based on financial management. The results of this study are in line with the results of research by Wibowo (2015) and Juita (2016). The results of the research indicated that accounting literacy has a positive influence on the sustainability of a business. This is because most of the owner understand about the accounting literacy. Accounting literacy help the owner to manage their business.

The third hypothesis of this study states that the transactional leadership style influences the sustainability of a business. The results of the hypothesis show that the transactional leadership style has a significant positive effect on the sustainability of a business, which means the third hypothesis is accepted. The transactional leadership style is different from financial literacy and accounting literacy in the relation to the RBT. In this study, the transactional leadership style is a part of human capital. Transactional leadership style is a form of human 


\section{PERFORMANCE}

Jurnal Personalia, Financial, Operasional,

Marketing dau Sistem Informasi

Performance. Volume 27 Nomor 2 Tahun 2020, 01-12

capital that discusses about leadership and skills. In this study leadership knowledge and the skills of the owner can influence the sustainability of the business. The utilization of human capital has a role to help maintain the sustainability of a business. The results of this study are in line with the results of Gürerk \& Scheuermann (2017). The results of the research indicated that the transactional leadership style has a positive influence on the sustainability of a business. This is because most of the industry are micro scale and small scale industries. In micro and small scale, they are more easily implement the culture of transactional leadership style. In this case, the owner use rewards and punishments to motivate their employees.

\section{CONCLUSION}

It can be concluded that all of independent variables have positive and significant effect to the dependent variable. This means that financial literacy, accounting literacy, and transactional leadership affects the sustainability of a business. Most of muffler industry owners understand the importance of financial literacy, accounting literacy, and transactional leadership style to help their business sustainability.

The implication for this research is the owner of the muffler industry needs the financial report. The owner needs to improve accounting literacy to make a good financial report. The knowledge of accounting literacy can develop and facilitate their business management in the financial sector. The good quality financial report can make the investor trust with the result of financial report. The good financial standard report can be easier for the owners to apply for loans from the creditor. To maximize the ability of financial management, the owner must frequently attend business development training. Internally, employers need to improve ways to motivate employees to work optimally. Limitation of this research consist due to the data collecting process. Whereas, during the collecting data process, there are some owner are outside the region. The process of filling the questionnaire research instrument must be carried out by families at least knows about the business. Hopefully, for further research it is expected to get the data is originally from the owner of mufflers industry.

\section{REFERENCE}

Aribawa, D. (2016). Pengaruh Literasi Keuangan terhadap Kinerja dan Keberlangsungan UMKM di Jawa Tengah. Jurnal Siasat Bisnis, Vol. 20 (1), 1-13.

Accounting Literacy. (2019). Accounting Standard. Accessed on 28 May 2019, from http://www.accountingliteracy.org/sai.html.

Barney, J. B. (1991). Firm resources and sustained competitive advantage. Journal of Management, 17: 99-120.

Bass, M. Bernard \& Riggio, E. Ronald. (2006). Transactional Leadership. Second Edition. New Jersey: Lawrence Erlbaum Associates, Inc.

Coates, Douglas J., M. Laurentius Marais, and Roman L. Weil. (2007). Audit Committee Financial Literacy: A Work in Progress. Journal of Accounting, Auditing \& Finance. 22 (2), 175-194.

Edirisooriya, W.A. (2014). Impact of Rewards on Employee Performance: With Special Reference to ElectriCo, Proceedings of the 3rd International Conference on Management and Economics (February 2014). Oral Presentations. pp. 311-318.

Edvinsson, L. \& Malone, M.S. (1997). Intellectual Capital: Realizing Your Company's True Value by founding it Hidden Brainpower. New York: Harper Business. 
Jurnal Personalia, Financial, Operasional,

Marketing dau Sistem Informasi

Performance. Volume 27 Nomor 2 Tahun 2020, 01-12

Fatoki, O. (2014). The Financial Literacy of Micro-Ownerss in South Africa. J See Sel, 40 (2).

Flynn, A. (2009). Sentence indications for indictable offences: Increasing court efficiency at the expense of justice? A response to the Victorian legislation. Australian \& New Zealand Journal of Criminology, 42(2), 244-268.

Gujarati, N Damodar (2013), Dasar-Dasar Ekonometrika. Edisi 5. Jakarta: Salemba Empat

Gürerk, O. Thomas Lauer, \& Martin Scheuermann. (2017). Leadership with Individual Rewards and Punishments: Do Incentives Reinforce Leading by Example. Munich Personal RePEC Archive, pp 1-28, mpra.ub.uni-muenchen.de/80413/.

Hills, Roderick M. and Roman L. Weil. (2004). Nuts and Bolts Guidance for Audit Committees. The Corporate Board. (September/October). pp. 1-6.

Handayani, N, (2007). Studi Deskriptif Kualitatif Tentang Keterkaitan Hubungan Modal Sosial Dengan Keberlangsungan Usaha Pengusaha Batik Di Kampung Kauman, Kelurahan Kauman, Kecamatan Pasar Kliwon, Surakarta), Laporan Penelitian. Universitas Sebelas Maret.

Juita, V. (2016). Pemanfaatan Sistem Informasi Akuntansi Pada Usaha Mikro, Kecil, Dan Menengah (UMKM) Sektor Jasa Perdagangan Di Padang, Sumatera Barat. Jurnal Riset Akuntansi Terpadu, 9(1) 120-137.

Kowalewski, S-J. \& Philips, S-L. (2012). Preferences for Performance-Based Employee Rewards: Evidence from Small Business Environments. International Journal of Management and Marketing Research, 6. pp 1-12.

Liu, Y. \& Akhtar Shamim. (2018). SMEs' Use of Financial Statements for Decision Making: Evidence from Pakistan. The Journal of Applied Business Research. 34(2), 381-392.

Nababan, D. (2012). Analisis personal financial literacy dan financial behavior mahasiswa strata I fakultas ekonomi Universitas Sumatera Utara.

Panekenan, R.M. Tumbuan W.J.F.A. Rumokoy F.S. (2019). The Influence of Reward and Punishment toward Employee's Performance at Bank Indonesia Branch Manado. Jurnal EMBA, 7(1), $471-480$.

Puspaningtyas, Z. (2017). Manfaat Literasi Keuangan Bagi Business Sustainability. Seminar Nasional Kewirausahaan dan Inovasi Bisnis VII. ISSN NO: 2089-1040.

Porter, M. (1985). Competitive strategy. New York: Free Press.

Pradana, T., \& Fuadati, S. R. (2016). Pengaruh Gaya Kepemimpinan Transaksional dan Budaya Organisasi terhadap Kinerja Karyawan, 5, 1-18.

Rosacker, K. M., Ragothaman, S. \& Gillispie, M. (2009). Financial Literacy of Freshmen Business School students. College Student Journal, 43(2), 391-399.

Roslan, N., Pauzi, N. F. M., Ahmad, K., Shamsudin, A., Karim, M. S., \& Ibrahim, S. N. S. (2018). Preliminary Investigation: Accounting Literacy among Small Business Owners. International Journal of Academic Research in Business and Social Sciences, 8(10), 32-47. 
Jurnal Personalia, Financial, Operasional,

Marketing dau Sistern Informasi

Performance. Volume 27 Nomor 2 Tahun 2020, 01-12

Saboet, H.V. (1994). Pentingnya Informasi Akuntansi dalam Kehidupan Manajemen. Majalah Ekonomi. No. 11.

Sangkala (2006). Intellectual Capital Management: Strategi Baru Membangun Daya Saing Perusahaan. Edisi Pertama, Penerbit Ikatan Penerbit Indonesia DKI Jakarta. ISBN: 979-327429-8.

Schaltegger, S., Ludeke-Freund, F., and Hansen, E.G. (2012). Business Cases for Sustainability: The Role of Business Model Innovation for Corporate Sustainability. International Journal of Innovation and Sustainable Development, Vol. 6 (2), 95-119.

Sugiyono. (2013). Statistika untuk Penelitian. Alfabeta: Bandung.

Tika, Muhammad Pabundu. (2006). Budaya Organisasi dan Peningkatan Kinerja Perusahaan. Jakarta: Bumi Aksara.

Wernerfelt, B. (1984). A resource-based view of the firm. Strategic Management Journal, 5: 171180.

Williams, I. (2005). Business report cards: Making sense from the numbers. International Journal of Commerce \& Management, 15(3), 300-301.

Wibowo, A. \& Kurniawati E-P. (2015). Pengaruh Penggunaan Informasi Akuntansi Terhadap Keberhasilan Usaha Kecil Menengah (Studi Pada Sentra Konveksi Di Kecamatan Tingkir Kota Salatiga). Jurnal Akuntansi, XVIII (2), 1979 - 6471.

Widayanti, R. Damayanti, R. Marwanti, F. (2017). Pengaruh Financial Literacy Terhadap Keberlangsungan Usaha (Business Sustainability) Pada UMM Desa Jatisari. Jurnal IImiah Manajemen dan Bisnis, 18(2), 153-163. 